\title{
Characterization of Research Nodes : An Integrative Approach Through Indexing
}

\author{
K. K. Das ${ }^{1 *}$, P. M. Bhattacharya ${ }^{1}$, A. Ghosh ${ }^{1}$, T. Dhar' ${ }^{1}$, K. Pradhan ${ }^{1}$, A. K. Chowdhury ${ }^{1}$, P. K. Joshi' ${ }^{2}$ and M. Gathala ${ }^{3}$ \\ ${ }^{1}$ Uttar Banga Krishi Viswavidyalaya, Pundibari, Coochbehar, West Bengal (736 165), India \\ ${ }^{2}$ International Food Policy Research Institute (IFPRI), New Delhi (110 012), India \\ ${ }^{3}$ International Maize and Wheat Improvement Centre (CIMMYT), Dhaka (12 12), Bangladesh
}

\section{Article History}

Manuscript No. AR1485

Received in $2^{\text {nd }}$ November, 2015

Received in revised form $24^{\text {th }}$ August, 2016

Accepted in final form $4^{\text {th }}$ October, 2016

\section{Correspondence to}

*E-mail:kkdas_ubkv@yahoo.com

\section{Keywords}

Developmental programmes, farming system index, kruskal-wallis test

\begin{abstract}
Appropriate understanding of situation is pre-requisite for effective implementation of a development programme or scheme. One of the serious drawbacks in failure of most of the developmental efforts (government, semi-government or non-government) is probably, poor understanding of the given situation. There are various parameters for characterising a situation and those (especially, the quantitative variables) are expressed in differential units too. The present study has been attempted to define/characterize research areas in terms of a unit free integrative approach namely, Farming System Index (FSI). This indexing approach is based on some defined scales on different variables. Development of FSI has been done by undertaking Focus Group Discussions in five nodes of Malda, a northern district in West Bengal. Data corresponds to agricultural year 2013-14. The selected nodes are characterised with the help of value of FSI which ranges from 0.51 to 0.59 which is indicative of the very fact that the village systems (i.e., node) lag substantially in development paradigm. Significance in difference among nodes with respect to various traits has been judged by following Kruskal-Wallis test followed by Bonferroni multiple comparison test. But, the source or cause of backwardness is not uniform in all the nodes. Accordingly prioritization of intervening issues has been done for each selected node which will be beneficial for effective implementation of future developmental programmes.
\end{abstract}

\section{Introduction}

Social development is, in general, understood as government policies and programmes concerned with the social aspect of development, such as reducing poverty, increasing literacy, combating malnutrition and improving access to health and education (Midgley, 2013) etc. It is in conformity with the Millennium Development Goals adopted at the United Nations Millennium Summit in New York in 2000 Development programmes. So developmental or research projects are undertaken with a certain clientele group in mind and of course, with an approximate geographical boundary in the back up. Accordingly, action plans or activities are designed/formulated and implemented. All these activities are aimed at improving the overall existing situation of the location/community. But, often, programmes fail to reach the target and the pace of progress does not make any substantial improvement. Several reasons (tangible or intangible) may be put forward for that. But one thing remains common:the planner or the researcher finds it difficult to comprehend the village situation in an integrative manner. Because, a rural framework is characterized by several independent or interdependent component like livelihood platform (consisting of natural capital, physical capital, human capital, financial capital, social capital), social relation/ system \& institutional framework, etc (Ellis, 2000). And every single component has its own peculiarityand thereby, has a definite role in progress or development of the system. When concentration/attention is focussed on an aspect, it may fail to achieve the potential benefit due to relative backwardness in the other. The system/environment in which the farm folk operate is characterised by tradition, belief, custom, festivals, social obligations etc. Managing decision or production decision is governed by composite influence of all these-directly or indirectly. A balancing approach, therefore, is highly essential for all-round development of a system. Therefore, for improving the plight of the farming folk, system approach, rather than the segregated approach, has to be thought of. That means, the focus will be not on any single enterprise/avocation/ aspect or not on a single individual/community or for a single time period but taking the system as a whole and in sustained manner :The Farming System. Understanding the farming system is thought to be an essential requisite for intensity of 
success of any development programme.

Knowledge about the farming system can be had by conducting techniques like Rapid Rural Appraisal (RRA) or Participatory Rural Appraisal (PRA) or more recently, by Focus Group Discussion/Interview (FGD). All these survey techniques have the potentiality to generate information about the characteristic features of the system on which a farming folk operates. The system is having several parameters and the fact remains that these parameters are expressed not in common units and they have got differential dimension too on the resultant/final output. The thing is that we have to synthesise and also (at the same time) to quantify the information so generated or obtained in integrated manner for its present use and possible future comparison in a meaningful way. Development of a unit free index may serve the purpose. It is the Farming System Index (FSI) to which we are referring. The present study is aimed at conceptualisation and also development of Farming System Index for characterising/describing a node (a village and its adjoining areas) in Malda, an important agrarian district in northern part of West Bengal.

\section{Materials and Methods}

\subsection{Sampling design}

The district of Malda in Eastern Gangetic Plain (EGP), which is characterised by high population density (1069 sq. $\mathrm{km}^{-1}$ ), great dependence on farming entrepreneurship (over 70\%), rather sluggish growth in agriculture (Statistical Abstract, 2008), low Human Development Index (HDI) etc. The district has a long boundary with its neighbouring country Bangladesh (about $165.5 \mathrm{~km}$ ) and trans-border infiltration of technology is a regular phenomenon here. Again, presence of three distinctly different agro-climatic zone, i.e., barind, (consisting mainly of old alluvial and relatively unfertile soil), tal (low laying and vulnerable to inundation during rainy season) and diara, (consists of very fertile land and is thickly populated) make it special. The district is selected purposively. Five nodes distributed over three blocks (namely, Chanchal, Manikchak, Gazole) covering all the above mentioned agro-climatic situations have been selected with certain stipulated criteria (presence of Farmers' Club, dominance of backward caste/minority population, market accessibility etc.). Characteristics of these villages and its adjoining areas has been grasped by conducting Focus Group Discussion where participants are exclusively of the area. Focus Group Discussions (FGD) have been conducted with participation of 12-15 individuals representing a group. Every care has been taken to include representation of all possible categories of farmers (male or female) in formation of the focus group in a node. Six (6) nos. of Focus Group Discussions have been conducted in a node, making the total FGD as 30 nos. in the district. An exhaustively prepared questionnaire has been used to elucidate the desired information. Culling of information is done by following the standard economic tools. Data pertains to agricultural year 2013-14. Standard econometric tool has been used in data analysis with the help of statistical software like SAS and SPSS.

\subsection{Concept of farming system index: FSI}

The Farming System Index (FSI) is a unit free concept where values of relevant selected variables are transformed into index in accordance with their respective defined scales (Table $3-7)$. The idea is developed by taking clue from the concept of WEAI (Women's Empowerment in Agriculture Index) developed by USAID (United States Agency for International Development) and IFPRI (International Food Policy Research Institute) in Shraboni et al, 2013 and the work of Bell \& Morse, 2008, Paul-Marie Boulanger, 2008 and others. The system is characterised by several major attributes (henceforth, called domain) like (A) general, (B) scope/opportunity in the form of resource endowment and (C) farming performance (D) Threat/Constraints/Weakness/Vulnerability. In addition, we are interested to explore the extent of (E) Feminizationin these nodes because, feminization in agriculture is believed to be an important aspect for overall development in farming sector in the coming days. So the construction of Farming System Indexwill be based on these five (5) basic domains. Each of these broad domains again constitutes of various sub-domains. As for example, demography, education\&food sufficiency are the sub-domains (components) of General domain (Table 1). Again, sub-domain demography has several selected sub-components (hence, called sub-subdomain) like size of households, family orientation, religion etc. (Table 2). It is presumed that all these sub-domains or sub-sub-domains have equal weightage in the respective domain or sub-domain.

\subsection{Mathematical expression}

$\mathrm{I}_{\mathrm{im}}=\left(\sum_{j=1}^{q} v_{i j m}\right) / \sum_{j=1}^{q} s_{j}=\stackrel{q}{\left(\sum v_{i j m}\right) / \mathrm{S}}$

$\mathrm{p}=$ Number of node

$\mathrm{t}=$ Number of Sub-domain (e.g. Demography, education, food sufficiency)

$\mathrm{q}=$ Number of sub-sub domain (e.g. size of household, per cent

\begin{tabular}{llc}
\hline \multicolumn{3}{l}{ Table 1: Domains of farming system index in Malda } \\
\hline Sl. No. & Domain & Assumed contribution \\
\hline 1. & General & Positive \\
2. & Resource endowment & Positive \\
3. & Farming performance & Positive \\
4. & Weakness/constraints & Negative \\
5. & Feminization & Positive \\
\hline
\end{tabular}

Constituent components of individual domains or subdomains are presented in Table 2 


\begin{tabular}{|c|c|c|}
\hline Domain & Sub-attribute & Sub-sub attribute \\
\hline \multirow[t]{3}{*}{ General } & Demography & $\begin{array}{l}\text { - Size of village households } \\
\text { - Female-headed households }(\%) \text { in village } \\
\text { - Households }(\%) \text { having manpower working outside } \\
\text { - Households }(\%) \text { having off-farm income sources }\end{array}$ \\
\hline & Education & $\begin{array}{l}\cdot \% \text { adult male having primary education (at least) } \\
\cdot \% \text { adult female having primary education (at least) } \\
\bullet \% \text { of village boys attending school at present } \\
\cdot \% \text { of village girls attending school at present }\end{array}$ \\
\hline & Food sufficiency & - $\%$ of households having food availability upto 10 months \\
\hline \multirow[t]{5}{*}{$\begin{array}{l}\text { Resource } \\
\text { endowment }\end{array}$} & General resource & $\begin{array}{l}\text { - Households (\%) having electricity connection } \\
\text { - Households }(\%) \text { having drinking water facility } \\
\text { - Households }(\%) \text { having LPG connection }\end{array}$ \\
\hline & Land resource & $\begin{array}{l}\cdot \text { Average size of holding household } d^{-1} \\
\cdot \% \text { agrcultural land to total land in the village } \\
\cdot \% \text { irrigated area in up-land situation } \\
\cdot \% \text { irrigated area in low and medium land situation }\end{array}$ \\
\hline & Mechanical resources & $\begin{array}{l}\text { - Nos. of 4-Wheel tractor } 1000 \text { households }^{-1} \\
\text { - Nos. of 2-Wheel tractor } 1000 \text { households }^{-1}\end{array}$ \\
\hline & Irrigation water & $\begin{array}{l}\text { - Overall } \% \text { of irrigated land in the village } \\
\cdot \% \text { electric operated tube-well }\end{array}$ \\
\hline & $\begin{array}{l}\text { Proximity to resource } \\
\text { facilities }\end{array}$ & $\begin{array}{l}\text { Agricultural Input shop, machinery repairing shop, service provider, } \\
\text { Soil testing facility, public extension service, credit institutions, output } \\
\text { market, health facility (Human and Animal) }\end{array}$ \\
\hline \multirow[t]{2}{*}{ Farm performance } & Seasonal void & $\begin{array}{l}\bullet \% \text { NCA remain void in } k \text { harif season } \\
\bullet \% \text { NCA remain void in rabi season } \\
\bullet \% \text { NCA remain void in pre-kharif (kharif-1) season }\end{array}$ \\
\hline & Crop productivity & - Respective major crops \\
\hline \multirow{3}{*}{$\begin{array}{l}\text { Weakness/ } \\
\text { constraints }\end{array}$} & Climatic $^{* *}$ & - Drought, flood, heat stress (severity and frequency) \\
\hline & Biological $^{* *}$ & -Weed, insect-pest, diseases (severity and frequency) \\
\hline & Others $^{* *}$ & $\begin{array}{l}\text { - Finance, labour availability, input availability, soil quality, machinery } \\
\text { availability }\end{array}$ \\
\hline \multirow[t]{2}{*}{$\begin{array}{l}\text { Feminization } \\
\text { (farm female) }\end{array}$} & $\begin{array}{l}\text { Participation in farm } \\
\text { activity }\end{array}$ & - Activity timing (\%) in farming \\
\hline & $\begin{array}{l}\text { Participation in decision } \\
\text { making* }\end{array}$ & $\begin{array}{l}\text { - Farming practices } \\
\text { - Farm finance } \\
\text { - Socio-cultural matters } \\
\text { - Others (casting of votes, separation etc.) }\end{array}$ \\
\hline
\end{tabular}

"Scales used: Never Consulted: 0; Consulted but not Implemented: 1; Consulted but partially implemented: 2; Consulted and fully implemented: 3; ${ }^{*}$ Scales used for Severity: Mild: 1; Moderate: 2, Severe: 3; For Frequency: Infrequently: 1; Some year: 2; Every year: 3

of Female-headed households, per cent of working family member outside village, Off-farm Income Source etc. under Sub-domain demography)

$\mathrm{k}=$ Number of replication (Focus Group) under each node Where,

$i=1,2 \ldots \ldots . p ; j=1,2$.. q; $k=1,2 \ldots \ldots . . r ; \quad m=1,2 \ldots \ldots . t$

Where, $\mathrm{S}=\sum_{j=1}^{q} S_{j}$

$\mathrm{S}_{j}=$ Maximum scale point of $\mathrm{j}^{\text {th }}$ sub-sub domain

$\mathrm{I}_{\mathrm{im}}=$ Index value of $\mathrm{m}^{\text {th }}$ sub domain under $\mathrm{i}^{\text {th }}$ node

$\mathrm{v}_{\mathrm{ijm}}=$ mean value of the $\mathrm{j}^{\text {th }}$ Sub-sub domain under $\mathrm{m}^{\text {th }}$ Subdomain in the $i^{\text {th }}$ node 
$\mathrm{D}_{u}=\frac{1}{\mathrm{t}} \sum_{\mathrm{m}=1}^{\mathrm{t}} W_{\mathrm{m}} \mathrm{I}_{i m}$

$\mathrm{W}_{m}=$ Weight of Sub-domain under domain in a particular node Where,

$\mathrm{u}=1,2 \ldots \ldots \ldots . . \mathrm{y}$

$y=$ total number of domain

$\mathrm{D}_{u}=$ Index value for $u^{\text {th }}$ domain

In case of Sub-domains presumed to be having negative contribution towards FSI, $1-\mathrm{D}_{\mathrm{u}}$ is taken as the corresponding Index value.

Farming system index $(\mathrm{FSI})=\frac{1}{n} \sum_{u=1}^{\mathrm{y}} W_{u} D_{u}$

$\mathrm{W}_{u}=$ Weight of $u^{\text {th }}$ domain in a particular node

$\mathrm{D}_{u}=$ Index value for $u^{\text {th }}$ domain

\subsection{Testing differences}

With the view in performing comparison of different attributes separately among different nodes, as well as several attributes within a particular node, the following two statistical procedures were employed (Deshpande et al., 1995, Dean and Voss, 1999):

(i) Testing the several independent samples

(ii) Multiple comparisons

One of the most important assumption associated with ANOVA is 'within each group/population, the response variable is normally distributed'. Under present investigation, most of the attributes/variables are qualitative/categorical in nature and finally the information collected was quantified by assigned score in different scale. So, in all cases normality assumption was violated and it was verified through carrying out WilkShapiro test $\left(\mathrm{H}_{0}\right.$ : Samples came from normal distribution). So, Kruskall-Wallis test $\left(\mathrm{H}_{0}\right.$ : all nodes effects are equal), the nonparametric analog to One-way Analysis of Variance was employed for testing the equality of several independent sample under different nodes with respect to a particular attribute, as well as several attributes within a particular node. The Kruskal-Wallis test statistic is based on the assessment of the difference among the average ranks. The Kruskal-Wallis statistics is, then, given by

$\mathrm{T}=\frac{12}{\mathrm{~N}(\mathrm{~N}+1)} \sum_{i}^{v}=1 \frac{\mathrm{R}_{t}^{2}}{\mathrm{r}_{i}}-3(\mathrm{n}+1)$

Where, $R_{i}=$ the sum of the ranks of the observations pertaining to the $\mathrm{i}^{\text {th }}$ node/group

$\mathrm{N}=$ total number of observation

$\mathrm{v}=$ number of node (for first situation)/attribute (for second situation)

$r_{i}=$ number of observation under $i^{\text {th }}$ node/attribute, $i=1,2$, $3 \ldots . . . \mathrm{v}$

$\mathrm{T}$ may be approximated by the chi-square with (v-1) degrees of freedom.

The situation where Kruskal-Wallis test rejects the null hypothesis $\left[\left(\mathrm{H}_{0}: \tau_{1}=\tau_{2}=-\ldots \ldots . . .=\tau_{\mathrm{v}}\right)\right.$, where, $\tau$ 's $=$ are the effects of different nodes/ attributes], Bonferroni test $\left(\mathrm{H}_{0}: \tau_{i}=\tau i\right.$ ') for multiple comparison was carried out using rank value of each observation.

\section{Results and Discussion}

\subsection{Domain I: general character}

Domain I namely, General domain consists of three selected sub-domains:demography, village education and food sufficiency scenario. Four (4) important parameters like average size (Nos.) of farm household, incidence (\%) of female-headed households in the village, extent (\%) of manpower working outside (both within or outside the state) the node and incidence of farm family having off-farm income sources constitute the sub-domain demography. The

Table 3 : Scales used for various sub-parameters under Domain I (General) of FSI

\begin{tabular}{|c|c|c|c|c|c|c|c|}
\hline \multirow[t]{2}{*}{ Sub-attribute } & \multirow[t]{2}{*}{ Sub-sub attribute } & \multirow{2}{*}{$\begin{array}{l}\text { Unit of } \\
\text { ex-pression }\end{array}$} & \multicolumn{5}{|c|}{ Measuring scale used } \\
\hline & & & 1 & 2 & 3 & 4 & 5 \\
\hline \multirow[t]{4}{*}{ Demography } & Size of farm households & Nos. & $<9$ & - & $<7$ & - & $<5$ \\
\hline & Female-headed households & $\%$ & $<45$ & - & $<30$ & - & $<15$ \\
\hline & Manpower working outside & $\%$ & 25 & $<25$ & $<20$ & $<15$ & $<10$ \\
\hline & Off- farm income sources & $\%$ & $\leq 20$ & $>20$ & $>30$ & $>40$ & $>50$ \\
\hline \multirow[t]{4}{*}{ Education } & Primary education (male) & $\%$ & $\leq 40$ & $>40$ & $>60$ & $>80$ & $=100$ \\
\hline & Primary education (female) & $\%$ & $\leq 40$ & $>40$ & $>60$ & $>80$ & $=100$ \\
\hline & $\begin{array}{l}\text { Present school going trend } \\
\text { (Boys) }\end{array}$ & $\%$ & $\leq 40$ & $>40$ & $>60$ & $>80$ & $=100$ \\
\hline & $\begin{array}{l}\text { Present school going trend } \\
\text { (girls) }\end{array}$ & $\%$ & $\leq 40$ & $>40$ & $>60$ & $>80$ & $=100$ \\
\hline Food sufficiency & $\begin{array}{l}\text { hh having food sufficiency upto } \\
10 \text { month from own production }\end{array}$ & $\%$ & $\leq 40$ & $>40$ & $>60$ & $>80$ & $=100$ \\
\hline
\end{tabular}


state of overall village education is understood by finding out percentage of male and female literacy (uptoV $\mathrm{V}^{\text {th }}$ standard) and present day schooling trend separately of village boys and girls. Similarly, information about food sufficiency is adjudged through identifying percentage of farm family having self-sustained food capacity for more than 10 months. A quick perusal of Table 8 gives an overview of nodal picture regarding general domain. Overall index for this domain ranges between

\begin{tabular}{|c|c|c|c|c|c|c|c|}
\hline \multirow[t]{2}{*}{ Sub-attribute } & \multirow[t]{2}{*}{ Sub-sub attribute } & \multirow{2}{*}{$\begin{array}{c}\text { Unit of } \\
\text { expression }\end{array}$} & \multicolumn{5}{|c|}{ Measuring scale used } \\
\hline & & & 1 & 2 & 3 & 4 & 5 \\
\hline \multirow[t]{3}{*}{ General resource } & Electricity connection (households) & $\%$ & $\leq 25$ & $>25$ & $>50$ & $>75$ & $=100$ \\
\hline & $\begin{array}{l}\text { Having drinking water supply } \\
\text { (households) }\end{array}$ & $\%$ & $\leq 25$ & $>25$ & $>50$ & $>75$ & $=100$ \\
\hline & Having LPG connection & $\%$ & $\leq 25$ & $>25$ & $>50$ & $>75$ & $=100$ \\
\hline \multirow[t]{4}{*}{ Land resource } & Agricultural land to total land & $\%$ & $\leq 60$ & $>60$ & $>70$ & $>80$ & $>90$ \\
\hline & Irrigated land (up) & $\%$ & $\leq 40$ & $>40$ & $>60$ & $>80$ & $=100$ \\
\hline & Irrigated land (low) & $\%$ & $\leq 40$ & $>40$ & $>60$ & $>80$ & $=100$ \\
\hline & Size of holding & lu & $\leq 4$ & $>4$ & $>5$ & $>6$ & $>7$ \\
\hline \multirow[t]{2}{*}{ Mechanical resource } & 4-Wheel tractor & Nos. $1000 \mathrm{hh}^{-1}$ & $\leq 2$ & - & $>2$ & - & $>3$ \\
\hline & 2-Wheel tractor & Nos. $1000 \mathrm{hh}^{-1}$ & $\leq 3$ & - & $>3$ & - & $>5$ \\
\hline \multirow[t]{7}{*}{ Proximity to resources } & Agricultural input shop & $\mathrm{km}$ & $\geq 5$ & - & $<3$ & - & $\leq 1$ \\
\hline & Machinery repairing shop & $\mathrm{km}$ & $\geq 5$ & - & $<3$ & - & $\leq 1$ \\
\hline & Service provider & $\mathrm{km}$ & $\geq 5$ & - & $<3$ & - & $\leq 1$ \\
\hline & Soil testing facility & $\mathrm{km}$ & $\geq 5$ & - & $<3$ & - & $\leq 1$ \\
\hline & Extension service & $\mathrm{km}$ & $\geq 5$ & - & $<3$ & - & $\leq 1$ \\
\hline & Financial institution & $\mathrm{km}$ & $\geq 5$ & - & $<3$ & - & $\leq 1$ \\
\hline & Output market & $\mathrm{km}$ & $\geq 5$ & - & $<3$ & - & $\leq 1$ \\
\hline \multirow[t]{3}{*}{ Irrigation } & $\begin{array}{l}\text { Households using canal water } \\
\text { (electric) }\end{array}$ & $\%$ & $\leq 40$ & $>40$ & $>60$ & $>80$ & $=100$ \\
\hline & Households using tube-well (electric) & $\%$ & $\leq 40$ & $>40$ & $>60$ & $>80$ & $=100$ \\
\hline & Households having irrigation resource & $\%$ & $\leq 40$ & $>40$ & $>60$ & $>80$ & $=100$ \\
\hline
\end{tabular}

Table 5: Scales used for various sub-parameters under domain III (farming performance) of FSI

\begin{tabular}{|c|c|c|c|c|c|c|c|}
\hline \multirow[t]{2}{*}{ Sub-attribute } & \multirow[t]{2}{*}{ Sub-sub attribute } & \multirow{2}{*}{$\begin{array}{c}\text { Unit of } \\
\text { expression }\end{array}$} & \multicolumn{5}{|c|}{ Measuring scale used } \\
\hline & & & 1 & 2 & 3 & 4 & 5 \\
\hline \multirow[t]{9}{*}{ Crop productivity } & Winter (kharif) paddy & $\mathrm{tha}^{-1}$ & $<3.0$ & $<3.5$ & $<4.0$ & $<4.5$ & $\geq 4.5$ \\
\hline & Wheat & $\mathrm{tha}^{-1}$ & $<2.0$ & $<3.0$ & $<4.0$ & $<5.0$ & $\geq 5.0$ \\
\hline & Mustard & $\mathrm{tha}^{-1}$ & $<1.0$ & $<1.5$ & $<2.0$ & $<2.5$ & $\geq 2.5$ \\
\hline & Lentil & $\mathrm{tha}^{-1}$ & $<1.0$ & $<1.5$ & $<2.0$ & $<2.5$ & $\geq 2.5$ \\
\hline & Maize & $\mathrm{tha}^{-1}$ & $<5.5$ & $<6.5$ & $<8.0$ & $<9.0$ & $\geq 9.0$ \\
\hline & Potato & $\mathrm{tha}^{-1}$ & $<20.0$ & $<22.5$ & $<25$ & $<30$ & $\geq 30$ \\
\hline & Tobaco & $\mathrm{tha}^{-1}$ & $<1.5$ & $<2.0$ & $<2.5$ & $<3.0$ & $\geq 3.0$ \\
\hline & Jute & $\mathrm{tha}^{-1}$ & $<1.0$ & $<2.0$ & $<2.5$ & $<3.0$ & $\geq 3.0$ \\
\hline & Summer (boro) paddy & $\mathrm{tha}^{-1}$ & $<5.0$ & $<5.0$ & $<6.0$ & $<6.5$ & $\geq 7.0$ \\
\hline \multirow{3}{*}{$\begin{array}{l}\text { Seasonal void } \\
\text { (out of net cropped area) }\end{array}$} & During kharif & $\%$ & $\geq 30$ & $<30$ & $<20$ & $<10$ & $=0$ \\
\hline & During rabi & $\%$ & $\geq 30$ & $<30$ & $<20$ & $<10$ & $=0$ \\
\hline & During kharif-1 & $\%$ & $\geq 30$ & $<30$ & $<20$ & $<10$ & $=0$ \\
\hline
\end{tabular}




\begin{tabular}{llllcl}
\hline \multicolumn{2}{l}{ Table 6: Scales used for various sub-parameters under domain IV (constraints/weaknesses) of FSI } \\
\hline Sub- & Sub-sub attribute & Unit of & \multicolumn{3}{c}{ Measuring scale used } \\
\cline { 4 - 6 } attribute & & expression & 1 & 2 & 3 \\
\hline Climatic & Drought & Scale & Mild, infrequent & Moderate, some year & Severe, every year \\
& Heat stress & Scale & Mild, infrequent & Moderate, some year & Severe, every year \\
& Flood & Scale & Mild, infrequent & Moderate, some year & Severe, every year \\
Biological & Insect-pest attack & Scale & Mild, infrequent & Moderate, some year & Severe, every year \\
& Disease incidence & Scale & Mild, infrequent & Moderate, some year & Severe, every year \\
& Weed infestation & Scale & Mild, infrequent & Moderate, some year & Severe, every year \\
Others & Financial crunch & Scale & Mild, infrequent & Moderate, some year & Severe, every year \\
& Labour availability & Scale & Mild, infrequent & Moderate, some year & Severe, every year \\
& Input availability & Scale & Mild, infrequent & Moderate, some year & Severe, every year \\
& Soil quality & Scale & Mild, infrequent & Moderate, some year & Severe, every year \\
& Machinery availability & Scale & Mild, infrequent & Moderate, some year & Severe, every year \\
\hline
\end{tabular}

Table 7: Scales used for various sub-parameters under domain V (feminization) of FSI

\begin{tabular}{|c|c|c|c|c|c|c|c|c|}
\hline \multirow[t]{2}{*}{ Sub-attribute } & \multirow[t]{2}{*}{ Sub-sub attribute } & \multirow{2}{*}{$\begin{array}{c}\text { Unit of } \\
\text { ex-pression }\end{array}$} & \multicolumn{6}{|c|}{ Measuring scale used } \\
\hline & & & 1 & 2 & 3 & 3 & 4 & 5 \\
\hline $\begin{array}{l}\text { Participation in farming } \\
\text { activities }\end{array}$ & $\begin{array}{l}\text { Time devoted for farming } \\
\text { activities }\end{array}$ & $\%$ & - & $\leq 20$ & $>20$ & $>30$ & $>40$ & $>50$ \\
\hline \multirow[t]{4}{*}{ Role in decision making* } & Farming practices & Score & $\mathrm{NC}$ & CBNI & CBPI & CFI & - & - \\
\hline & Financial matters & Score & $\mathrm{NC}$ & CBNI & CBPI & CFI & - & - \\
\hline & Socio-cultural aspects & Score & $\mathrm{NC}$ & CBNI & CBPI & CFI & - & - \\
\hline & Others & Score & $\mathrm{NC}$ & $\mathrm{CBNI}$ & CBPI & CFI & - & - \\
\hline
\end{tabular}

${ }^{*} J u d g e d$ in 4-point scale basis $(0,1,2,3)$; NC: Never consulted (0); CBNI: Consulted but never implemented (1); CBPI: Consulted but partially implemented (2); CFI: Consulted and fully implemented (3)

0.56 to 0.63 . Node-I (Ugritola) of Manikchak block is found to be having lowest index value of 0.56 . This is because of the fact that the node substantially lags in demographic features; it is having average farm family size of 7 or more, greater percentage (33\%) of female head households etc. Compared to this, Mohadipur (Sub-domain index 0.63) or Gourangapur (Sub-domain index 0.63) nodes are having farm family size of 5 and female-headed household of $15-20 \%$ only. In general, picture regarding standard of education and food sufficiency is good in these nodes. Kruskal-Wallis (K-W) Test identified nodal difference with respect to food sufficiency situation.

\subsection{Domain II: resource endowment}

After identifying the general feature of the village system, focus is laid on exploring the village resource situation, the domain II. It is constituted of five sub-domains like general resources, land resources, mechanical resources, water resources and proximity to various facilities like market, financial institutions, extension offices etc. Resources like extent (per cent of households) of electrification, extent (per cent of households availing) of drinking water facility, extent of LPG connection constitute the sub-domain general resource (sub-domain I). Village land constitutes an important natural capital. Information regarding extent of agricultural land to total village land, incidence of up, low and medium land, average size of holding have been culled to get an overall picture on this aspect. In general, farming

\begin{tabular}{|c|c|c|c|c|c|c|}
\hline \multicolumn{7}{|c|}{ Table 8: Component-wise indexing of general domain } \\
\hline \multirow{2}{*}{$\begin{array}{l}\text { Sub- } \\
\text { domain }\end{array}$} & \multicolumn{5}{|c|}{ Sub-domain index (SDI) for } & \multirow{2}{*}{$\begin{array}{c}\chi^{2} \text { value } \\
\text { (Kruskal-wallis } \\
\text { test) }\end{array}$} \\
\hline & 1 & 2 & 3 & 4 & 5 & \\
\hline $\begin{array}{l}\text { Demogra- } \\
\text { phy }\end{array}$ & 0.43 & 0.49 & 0.68 & 0.48 & 0.62 & $7.09^{\mathrm{NS}}$ \\
\hline Education & 0.65 & 0.69 & 0.63 & 0.72 & 0.67 & $0.83^{\mathrm{NS}}$ \\
\hline $\begin{array}{l}\text { Food suf- } \\
\text { ficiency }\end{array}$ & 0.60 & 0.55 & 0.60 & 0.60 & 0.60 & $14.31^{* * *}$ \\
\hline Overall & 0.56 & 0.58 & 0.63 & 0.60 & 0.63 & \\
\hline \multicolumn{7}{|c|}{$\begin{array}{l}{ }^{*}: p<0.10 ;{ }^{* *}: p<0.05 ;{ }^{* * *}: p<0.001 ; \text { NS: Non significant; } 1 \\
\text { Ugritola (Node-I); } 2: \text { Vidyanandapur (Node-I); 3: M'Pur } \\
\text { Mahadipur (Node-III); 4: Kalinagar (Node-IV); 5: G'Pur } \\
\text { Gourangapur (Node-V) }\end{array}$} \\
\hline
\end{tabular}


situation in West Bengal lags in mechanisation aspect. These villages are no exception to that. Extent of mechanisation is assessed by exploring the

availability of farm machineries like 2-wheel tractor, 4-wheel tractor, irrigation pump, thresher, harvester, laser land leveller (LLL) etc. within the village. Information regarding hydrological (water) resources is obtained by identifying the main source where from irrigation water is supplemented. Along side physical resources, an idea about the proximity towards various facilities has been obtained. The index value for this domain ranges from 0.50 to 0.59 (Table 9). It can be presumed that Gourangapur node (No. V) of Gazole block is most resourceful node and Mahadipur is the most resource poor among these five nodes. Mechanisation aspect is too poor (index 0.25-0.40) in all these nodes except in Gourangapur (Node-V). Average nos. of 2-wheel tractor $\left(1000\right.$ households $\left.^{-1}\right)$, 4-wheel tractor $\left(1000\right.$ households $\left.^{-1}\right)$ are relatively more here. Also, 22\% households are having pump machine, $43 \%$ is having sprayer as protection device. But Gourangapur is backward in terms of general resources [LPG connection 6\%), drinking water facility $0 \%$ ]. Baring poor mechanisation aspect (index 0.25) land situation (50\% up land area) and irrigation potential (65\% for upland, $58 \%$ for low and medium type of land) in Mahadipur happens to be in disadvantageous position too. All the resource facilities are very much in nearby areas in Ugritola and the corresponding index is maximum (0.90) there. Kruskal-Wallis (K-W) Test identified nodal difference with respect to mechanical resources and proximity to resources. Mechanical resources in Node-V (Gourangapur) is significantly better than other nodes. With regard to resource proximity, Node-I (Ugritola) is in a significantly better position than others.

Table 9: Component-wise indexing of resource Endowment domain

\begin{tabular}{|c|c|c|c|c|c|c|}
\hline \multirow{2}{*}{$\begin{array}{l}\text { Sub- } \\
\text { domain }\end{array}$} & \multicolumn{5}{|c|}{ SDI } & \multirow{2}{*}{$\begin{array}{c}\chi^{2} \text { value } \\
\text { (Kruskal- } \\
\text { Wallis test) }\end{array}$} \\
\hline & 1 & 2 & 3 & 4 & 5 & \\
\hline General & 0.43 & 0.47 & 0.53 & 0.42 & 0.40 & $1.08^{\mathrm{NS}}$ \\
\hline Land & 0.63 & 0.75 & 0.50 & 0.73 & 0.62 & $5.82^{\mathrm{NS}}$ \\
\hline $\begin{array}{l}\text { Mecha- } \\
\text { nisation }\end{array}$ & 0.40 & 0.25 & 0.25 & 0.40 & 0.87 & $17.20^{\mathrm{NS}}$ \\
\hline Irrigation & 0.46 & 0.49 & 0.57 & 0.63 & 0.55 & $1.95^{\mathrm{NS}}$ \\
\hline $\begin{array}{l}\text { Resource } \\
\text { proximity }\end{array}$ & 0.90 & 0.59 & 0.66 & 0.62 & 0.50 & $26.99^{* * *}$ \\
\hline Overall & 0.56 & 0.51 & 0.50 & 0.56 & 0.59 & \\
\hline
\end{tabular}

\subsection{Domain III: farming performance}

Domain III (farming performance) is consisting of two sub-domains namely, seasonal land utilization scenario and productivity pattern of major crops in a node. Average index value of nodes in this regard ranges from 0.39 to 0.50 (Table 10) which does indicate that the nodes are substantially backward in this respect. Though there remains gross similarity in major crops cultivation, the nodes do differ in major cropping sequence. While kharif paddy-mustard-maize is the prime cropping sequence in Gourangapur (Node-V), it is kharif paddy-wheat-fallow in Ugritola (Node-I). Again, Mahadipur remains far behind the other nodes - be it in terms of seasonal void area or crop productivity. About $30 \%$ of cultivable land in kharif 1 season, about $21-22 \%$ in rabi season and 8-9\% in kharif season remain void and thus making the Intensity of Cropping 240\%. Kruskal-Wallis (K-W) Test identified nodal difference with respect to crop yield performance which is relatively worse in Node-III than others. Kharif paddy (aman), wheat, mustard, summer paddy (boro), jute etc. are the principal crops in Mahadipur with ensuing trend of little bit seasonal vegetable cultivation. Kharif paddy-wheat-fallow is the principal cropping sequence here.

Yield performance is reflective of the overall district performance in this regard. The information on yield of various crops received from farmers indicate that kharif (aman) paddy yield is moderate and is in the range of $3.35 \mathrm{tha}^{-1}$ to $3.92 \mathrm{tha}^{-1}$. Of course, kharif paddy yield performance in all the nodes is far better than the corresponding district average ( $2.73 \mathrm{t} \mathrm{ha}$ $\left.{ }^{1}\right)$, state average $\left(2.49 \mathrm{t} \mathrm{ha}^{-1}\right)$ or national average $\left(2.28 \mathrm{t} \mathrm{ha}^{-1}\right)$ [secondary data corresponds to the year 2011-12]. With regard to summer paddy too, the overall performance $\left(5.6 \mathrm{tha}^{-1}\right.$ to 5.75 $\mathrm{t} \mathrm{ha}^{-1}$ ) is better than the district/state/national average. Summer (boro) paddy cultivation is mainly concentrated in the nodes of Chanchal block. But with respect to mustard, an important rabi crop in the existing sequence, yield performance is either at par (Node-I, II, IV, V) or far below (Node-III) the district $\left(1.12 \mathrm{t} \mathrm{ha}^{-1}\right)$, state $\left(0.99 \mathrm{t} \mathrm{ha}^{-1}\right)$ or national average (1.13 t ha$\left.{ }^{1}\right)$. The point of concern is that both yield and area coverage under mustard in Malda district has become rather asymptotic

\begin{tabular}{lcccccc}
\hline \multicolumn{6}{l}{ Table 10: Component-wise indexing of farming performance } \\
\hline $\begin{array}{l}\text { Sub- } \\
\text { domain }\end{array}$ & 1 & 2 & 3 & 4 & 5 & $\begin{array}{c}\chi^{2} \text { value } \\
\text { (Kruskal-Wallis } \\
\text { test) }\end{array}$ \\
\cline { 2 - 7 } & & & & & & $1.37^{\mathrm{NS}}$ \\
\hline $\begin{array}{l}\text { Seasonal } \\
\text { void }\end{array}$ & 0.53 & 0.58 & 0.51 & 0.63 & 0.53 & $12.42^{*}$ \\
$\begin{array}{l}\text { Crop pro- } \\
\text { ductivity }\end{array}$ & 0.38 & 0.40 & 0.27 & 0.37 & 0.40 & \\
Overall & 0.45 & 0.49 & 0.39 & 0.50 & 0.47 \\
${ }^{*}: p<0.10 ;{ }^{* *}: p<0.05 ;{ }^{* * *}: p<0.001 ; \mathrm{NS}:$ Non significant
\end{tabular}


over the years. Same is the case for jute. The yield of jute in the range of $1.2 \mathrm{t} \mathrm{ha}^{-1}$ (Mohadipur, Node-III) to $2.01 \mathrm{t} \mathrm{ha}^{-1}$ (Node-1, V) is a matter of concern, no doubt. It is far below the state $\left(2.57 \mathrm{t} \mathrm{ha}^{-1}\right)$ or national $\left(2.59 \mathrm{tha}^{-1}\right)$ or even district $\left(2.74 \mathrm{t} \mathrm{ha}^{-1}\right)$ average. Moreover, jute yield in Malda district is on the rise despite of the declining trend in area coverage. Area allocation under wheat crop is asymptotic over the years though yield performance is on the rise. Excepting two nodes under Gazole block, all the other nodes have level of wheat yield below par the corresponding district $\left(2.99 \mathrm{t} \mathrm{ha}^{-1}\right)$, state $\left(2.77 \mathrm{tha}^{-1}\right)$ or national $\left(3.18 \mathrm{tha}^{-1}\right)$ average. On the contrary, the nodes (excepting Node-II \& III) are performing better in pulse crop (lentil) cultivation. Overall productivity of total pulses is also on rise. Traditionally, the district of Malda was a pulse growing area in Bengal farming system. But over the years, area under pulse crops decline due to various reasons. This may be indicative about possible intervening point in the cropping sequence. Thus, gap in individual crop yield or in the cropping system as a whole warrants deep insight and judicious thinking on existing crops and cropping sequence in these nodes.

\subsection{Domain IV: resilience to weaknesses}

Now, focus is shifted to identify the inherent weaknesses in the village farming system in each of these nodes. Domain IV (Constraints/Weaknesses) is understood by grasping idea about three major sub-domains namely, climatic constraints, biological constraints and other or miscellaneous type of constraints. In climatic vulnerability, severity and frequency of drought (at different crop growth stage), flood, occurrence of monsoon rainfall, heat stress are considered. Similarly, for biological constraints, risks in terms of disease, pest and weed incidence were enumerated. In addition to these two constraints, a farming system is subjected to many other vulnerabilities like financial crunch, soil quality degradation, inputs non availability etc. and indices of each of these variables in respective node are found out. For compatibility in overall calculation of Farming System Index, corresponding values of each sub-domain in this domain are subtracted from the maximum attainable value i.e., 1.0. Kruskal-Wallis (KW) Test identified nodal difference with respect to biological constraints and in this regard, Node-I is relatively better (less vulnerability) than other nodes.

Overall indices for resilience to constraints or weaknesses vary from 0.49 (in Node-IV \& V, Kalinagar, Gourangapur respectively) to 0.64 (Node-I, Ugritola). Node-I is quite good in respect of hazards like quality degrading nature of soil, disease-pest-weed incidence, non-availability of labour etc. But the node is relatively vulnerable to farm machinery nonavailability or climatic hazards especially intermittent flood $\&$ drought. Among biological constraints, Node-II, IV and Node-V are greatly affected. Again, Node-III \& IV are severely affected by non-availability of manpower especially during peak period demand (Table 11). More than 50\% households, in these nodes, are having family member(s) remaining outside the village for a substantial period of the year. It is quite interesting to note that though the nodes, in general, are having shortage in required nos. of farm implements (ownership), nonavailability of it is not a problem there. That is, the requirement is met by hiring in from neighbouring areas. It's a fact that farm mechanisation is on upswing in the state but the rate of progress is too slow. Shortage of trained manpower, availability of be-fitting machinery etc. are thought to the issues which need to be addressed in all these nodes, in general. Establishment of Farm Implement Hub in the vicinity of the nodes may be an ideal option on the matter. Low investment capacity is a serious problem in Node-II (Mahadipur).

\subsection{Domain V: feminization}

Alongside understanding the pros and cons in village farming system, an understanding of the role played by farm women is thought to be necessary as an important domain of the farming system as a whole in these nodes. Because, women play a significant role in agriculture, the World over. Throughout the South Asian region, women account for about 39\% of the agricultural workforce, working as managers of land to agricultural labourers as per the IFPRI. According to the FAO,

Table 11: Component-wise indexing of resilience to Constraint/ Weakness

\begin{tabular}{|c|c|c|c|c|c|c|}
\hline \multirow{2}{*}{$\begin{array}{l}\text { Sub- } \\
\text { domain }\end{array}$} & \multicolumn{5}{|c|}{ SDI } & \multirow{2}{*}{$\begin{array}{c}\chi^{2} \text { value } \\
\text { (Kruskal- } \\
\text { Wallis test) }\end{array}$} \\
\hline & 1 & 2 & 3 & 4 & 5 & \\
\hline $\begin{array}{l}\text { Climate } \\
\text { related }\end{array}$ & 0.57 & 0.61 & 0.61 & 0.48 & 0.51 & $2.27^{\mathrm{NS}}$ \\
\hline Biological & 0.69 & 0.25 & 0.44 & 0.28 & 0.15 & $10.21^{* *}$ \\
\hline $\begin{array}{l}\text { Financial } \\
\text { crunch }\end{array}$ & 0.59 & 0.26 & 0.56 & 0.56 & 0.56 & $4.12^{\mathrm{NS}}$ \\
\hline $\begin{array}{l}\text { Quality } \\
\text { degradation } \\
\text { of soil }\end{array}$ & 0.78 & 0.61 & 0.56 & 0.56 & 0.51 & $3.64^{\mathrm{NS}}$ \\
\hline $\begin{array}{l}\text { Inputs non- } \\
\text { availability }\end{array}$ & 0.61 & 0.72 & 0.89 & 0.81 & 0.81 & $5.56^{\mathrm{NS}}$ \\
\hline $\begin{array}{l}\text { Farm } \\
\text { machinery } \\
\text { non- } \\
\text { availability }\end{array}$ & 0.54 & 0.65 & 0.69 & 0.63 & 0.51 & $3.89^{\mathrm{NS}}$ \\
\hline $\begin{array}{l}\text { Non } \\
\text { availability } \\
\text { of labour }\end{array}$ & 0.69 & 0.52 & 0.11 & 0.11 & 0.41 & $2.35^{\mathrm{NS}}$ \\
\hline Overall & 0.64 & 0.52 & 0.55 & 0.49 & 0.49 & \\
\hline
\end{tabular}


while the proportion of the labour force working in agricultural work declined over the 1990s, the proportion of women working in agriculture increased, particularly in developing countries. In some regions such as Africa and Asia, almost half of the labour force is women. This feminisation of agriculture is caused by increased casualization of work, unprofitable crop production and distress migration of men for higher casual work in agriculture and non-agriculture. An understanding of the above narrated phenomenon has been judged by exploring their role both in (1) participation in farming activities as well as (2) in decision making on farm and family matters. Because, the human development concept, by concentrating on choices, implies that influence the processes that shape theirlives. They must participate in various decision making processes, the implementation of those decisions, and their monitoring and adjustment to improve outcomes where necessary.

The women in these nodes participate in farming activities along with the household works including maintenance of livestock. But there remain the basic facts of tradition, custom, belief behind the specific role played by women in these societies. Keeping in mind all these factors, it is simply attempted to understand the magnitude of women's participation in farm and non-farm activities. Women, in general, spend $42 \%$ to $55 \%$ t of a day (assumed effectively to be of $16 \mathrm{hrs}$.) for household activities. Women of both the nodes of Gazole block spend comparatively more time (51\% to $58 \%$ ) in farming operations. Non-farm activities including leisure is almost absent in these two nodes of Gazole. Women of Node-II of Chanchal block spend only $25 \%$ time for farm activities. They enjoy the highest leisure time. Kruskal-Wallis (K-W) Test identified nodal difference with respect to decision making by women in a farm family. Bonferroni Multiple Comparison test identified that Node-IV \& V are significantly far ahead than others in this regard (Table 12).

\subsection{Overall farming system index (FSI)}

Thus, overall Farming System Indices for nodes under study are found to be in the range of 0.51 to 0.59 (Table 13) which is indicative of the fact that the system lags far behind the targeted goal (i.e., 1.0). Each node is having its strength and drawbacks/lacuna to arrive at the final value of FSI. Overall FSI for Node-V (Gourangapur) is 0.59 in which the index regarding general characters i.e education, food sufficiency etc. is quite good. The node is moderately endowed with land or mechanical resources. Also, there is very good progress in this node from feminization point of view. But, the node lags substantially in terms of farming performance (seasonal void, low productivity) and in different kinds of constraints (insect-pest-disease-weed infestation). Like-wise, every node has FSI differential and having inherent strength and weaknesses. Accordingly, prioritization of intervening issues has to be decided.

Table 12: Component-wise indexing of feminization in agriculture

\begin{tabular}{|c|c|c|c|c|c|c|}
\hline \multirow[t]{2}{*}{ Sub-domain } & \multicolumn{5}{|c|}{ SDI } & \multirow{2}{*}{$\begin{array}{l}\chi^{2} \text { value } \\
\text { (Kruskal- } \\
\text { Wallis test }\end{array}$} \\
\hline & 1 & 2 & 3 & 4 & 5 & \\
\hline $\begin{array}{l}\text { Participa- } \\
\text { tion in } \\
\text { farming } \\
\text { activities }\end{array}$ & 0.36 & 0.40 & 0.45 & 0.47 & 0.80 & $4.74^{\mathrm{NS}}$ \\
\hline $\begin{array}{l}\text { Decision } \\
\text { making } \\
\text { process of } \\
\text { farm family }\end{array}$ & 0.49 & 0.65 & 0.56 & 0.73 & 0.73 & $13.59^{* * *}$ \\
\hline Overall & 0.43 & 0.52 & 0.50 & 0.60 & 0.76 & \\
\hline
\end{tabular}

\subsection{Research priority areas in the nodes}

So, we grasp an idea about the relative unit-free measure of different selected domains and its constituent parameters for each node under the district. It definitely gives an insight into the existing strength (in terms of resource base-human and materialistic) and vulnerability in village situation. Alongside,

\begin{tabular}{lccccc}
\hline \multicolumn{6}{c}{ Table 13: Node-wise farming system index (FSI) } \\
\hline Sub-domain & 1 & 2 & 3 & 4 & 5 \\
\cline { 2 - 6 } & 0.56 & 0.58 & 0.63 & 0.60 & 0.63 \\
General character & 0.56 & 0.51 & 0.50 & 0.56 & 0.59 \\
$\begin{array}{l}\text { Resource } \\
\text { endowment }\end{array}$ & 0.45 & 0.49 & 0.39 & 0.50 & 0.47 \\
$\begin{array}{l}\text { Farming } \\
\text { performance }\end{array}$ & & & & & \\
Weakness & 0.64 & 0.52 & 0.55 & 0.49 & 0.49 \\
$\begin{array}{l}\text { Feminization } \\
\text { Overall FSI }\end{array}$ & 0.43 & 0.52 & 0.50 & 0.60 & 0.76 \\
${ }^{*}: p<0.10 ;{ }^{* *}: p<0.05 ;{ }^{* * *}: p<0.001 ;$ & NS: Non significant
\end{tabular}

we grasp an idea about the context of feminization in agriculture in these nodes. Some of these demand intervention on attitudinal/behavioural (as for example, commercial vs. subsistence look towards farming) change, some may demand for intervention on current package of practices (like cropping system, input using, varietal selection, etc.) while some other may warrant intervention on policy matters (like Minimum Support Price (MSP) for Crops, Subsidization on farm implements procuring, irrigation water accessibility, women empowerment etc.) or institutional factors (like credit availability and accessibility, food sufficiency, market 
infrastructure etc.). It is also the fact that not all these parameters are having equal importance in all the nodes. It is, therefore, necessary for apt prioritization of these parameters in a rational manner (Erenstein et al, 2007). We sought for ranking technique for assessing relative position (Table 14) of an individual parameter in the developed FSI which will help us in identifying the area of intervention while framing up the project activities. While prioritising, we are, of course, guided by the corresponding index value and field experience of the scientists.

\begin{tabular}{llllll}
\hline \multicolumn{6}{l}{ Table 14 : Node-wise prioritization of major intervening areas in Malda } \\
\hline RPA & \multicolumn{5}{c}{ Priority areas for intervention in individual node } \\
\cline { 2 - 6 } & \multicolumn{1}{c}{$\begin{array}{c}\text { Ugritola } \\
\text { (node-I) }\end{array}$} & \multicolumn{1}{c}{$\begin{array}{c}\text { V'Pur } \\
\text { (node-II) }\end{array}$} & \multicolumn{1}{c}{$\begin{array}{c}\text { M'pur } \\
\text { (node-III) }\end{array}$} & $\begin{array}{c}\text { Kalinagar } \\
\text { (node-IV) }\end{array}$ & \multicolumn{1}{c}{$\begin{array}{c}\text { G'Pur } \\
\text { (node-V) }\end{array}$} \\
\hline $1^{\text {st }}$ & Crop productivity & Farm mechanisation & NAL & NAL & Biological constraints \\
$2^{\text {nd }}$ & Farm mechanisation & Biological constraints & Farm mechanisation & Biological constraints & Crop productivity \\
$3^{\text {rd }}$ & Intensity of cropping & Crop productivity & Crop productivity & Crop productivity & NAL \\
$4^{\text {th }}$ & Biological constraints & NAL & Biological constraints & Farm mechanisation & Irrigation \\
$5^{\text {th }}$ & NAL & Intensity of cropping & Intensity of cropping & Irrigation & Intensity of cropping \\
\hline
\end{tabular}

RPA: Rank of priority area; NAL: Non availability of labour

\section{Conclusion}

The study characterised each selected nodes in Malda district basing on its obtained Farming System Index. Indices of individual domain and sub-domain in each node indicates about inherent strength (s) and weaknesses in the respective village system. Though there are many areas of intervention, the instant study enlisted 5 major areas like farm mechanisation, crop productivity, cropping system, labour non availability, insect-disease-weed problems etc in selected nodes of the district. These issues, in general, warrant thorough insight and proper remedial measure (s).

\section{Acknowledgement}

This paper is drawn from a Report entitled "Understanding the Village Farming System in West Bengal - a participatory approach" for an ACIAR (Australian Centre for International Agricultural Research) and CIMMYT project "Sustainable and Resilient Farming Systems Intensification in the Eastern Gangetic Plains (SRFSI)". The authors duly acknowledge the patience and cooperation of Focus Group participants during discussion. Also, we solemnly owe our indebtedness to ACIAR and CIMMYT for all kinds of help in carrying out the work.

\section{References}

Annonymous, 2008. Statistical Abstracts, 2008. Bureau of Applied Economics and Statistics, Government of West Bengal.

Annonymous, 2012. District Handbook 2012 :Malda. Bureau of Applied Economics and Statistics, Government of West Bengal, Kolkata.

Bell, Simon., Morse, Stephen. 2008. Sustainability indicators -measuring the immeasurable? Earthscan, London.

Boulanger, Paul-Marie, 2008. Sustainable development indicators: a scientific challenge, a democratic issue. S.A.P.I.EN.S.

Dean, A., Voss, D., 1999. Design and analysis of experiments. Springer Texts in Statistics, Springer, New York.

Deshpande, J.V., Gore, A.P., Shanubhogue, A., 1995. Statistical analysis of non-normal data. Wiley Eastern Ltd., New Delhi.

Ellis, F., 2000. Rural livelihoods and diversity in developing countries. Oxford University Press.

Erenstein, Olaf, Hellin, J., Chandna, P., 2007. Livelihoods, poverty and targeting in the Indo-gangetic plains:a spatial mapping approach. A CIMMYT and RWC Research Report. CIMMYT and Rice-Wheat Consortium for the Indo-gangetic plains, New Delhi.

Midgley, James, 2013. Social development: theory and practice. SAGE, New Delhi.

Sraboni, E., Quisumbing, A.R., Ahmed, A.U., 2013. The women's empowerment in agriculture index: results from the 2011-2012 Bangladesh Integrated Household Survey. International Food Policy Research Institute, Dhaka. Available from http://www.a4nh.cgiar.org/ files/2013/04/IFPRI-PRSSP_Bangladesh-WEAIReport_Final_14-April-2013.pdf 